\title{
Characterization of an Unusual Cytoplasmic Chimera Detected in Bolting Garlic Clones
}

\author{
Meryem Ipek \\ Department of Horticulture, University of Wisconsin, 1575 Linden Drive, Madison, WI 53706 \\ and Çanakkale Onsekiz Mart University, Faculty of Agriculture, Department of Horticulture, \\ Çanakkale 17020, Turkey
}

\begin{abstract}
Ahmet Ipek
Department of Horticulture, University of Wisconsin, 1575 Linden Drive, Madison, WI 53706

and Uludag University, Faculty of Agriculture, Department of Horticulture, Görikle, Bursa 16059, Turkey
Douglas Senalik and Philipp W. Simon ${ }^{1}$
Department of Horticulture, University of Wisconsin, 1575 Linden Drive, Madison, WI 53706
and U.S. Department of Agriculture-Agricultural Research Service, Vegetable Crops Research Unit, 1575 Linden Drive, Madison, WI 53706
\end{abstract}

\begin{abstract}
AdDitIONAL INDEX wORDs. Allium sativum, marker, flowering, mitochondria, plastid
Abstract. Production of a visible flower stalk, or bolting, has been used as a major trait to categorize garlic (Allium sativum L.) clones. Analysis of mitochondrial genome variation with polymerase chain reaction (PCR) revealed differences between bolting and nonbolting clones of garlic. Screening 333 garlic accessions from diverse geographic origins revealed a 1403-bp mitochondrial DNA marker associated with bolting that the authors call "Bolt Marker" (BltM). Bolt Marker did not amplify in any of the 131 nonbolting clones, whereas amplification of this marker was observed in 127 of $130(97.7 \%)$ garlic clones that bolted completely in Wisconsin. Seventy-two garlic clones bolted incompletely (clones in which some but not all of the plants bolted), and this marker was not amplified in 69 (95.8\%) of these clones. Because of the significant association of BItM with bolting, this PCR-based marker can be used to discriminate complete-bolting garlic clones reliably from nonbolting and incomplete-bolting ones. Sequence characterization of this marker revealed that BItM is a chimera involving both mitochondrial and chloroplast DNA. The DNA sequences including and flanking both the $5^{\prime}$ and $3^{\prime}$ ends of this marker are consistent with an $\approx 4.8$ kbp chloroplast DNA fragment having been inserted into the mitochondrial genome downstream from the mitochondrial cox3 gene. Sequence alignment of the chloroplast genes in this chimeric region with the homologous sequences in GenBank indicate the presence of deletions, insertions, and single nucleotide polymorphisms in the coding sequences, resulting in putative, incomplete open reading frames or frame shift mutations. Hence, the authors speculate that this insertion may have occurred long ago in the evolution of garlic.
\end{abstract}

Garlic is a clonally propagated and economically important horticultural crop known from antiquity $(>5000$ years) (Etoh and Simon, 2002). Although it has been propagated clonally, many garlic clones vary widely in morphological characteristics such as rate of crop maturity, bulb size and color, clove size and number, leaf number and color, and bolting habit. Variation observed in genetic diversity studies using molecular markers is as wide as that observed for phenotypic variation among the garlic clones (Ipek et al., 2003; Maass and Klaas, 1995; Pooler and Simon, 1993). Because garlic was considered to be an obligate apomict (Koul et al., 1979) until recently, the source of wide phenotypic and molecular diversity observed in garlic was uncertain (Etoh and Simon, 2002). However, within the last 15 years, true seed production via sexual reproduction in garlic has been demonstrated, and it is now thought that variation created by genetic recombination is the basis for

Received for publication 15 Oct. 2006. Accepted for publication 2 June 2007. Mention of trade names or commercial products in this publication is solely for the purpose of providing specific information and does not imply recommendation or endorsement by the University of Wisconsin or U.S. Department of Agriculture.

${ }^{1}$ Corresponding author. E-mail: psimon@wisc.edu. differences observed among existing garlic clones, and it provides a significant tool for future garlic improvement (Etoh and Simon, 2002; Ipek et al., 2005; Simon and Jenderek, 2003, Zewdie et al., 2005).

Of all the varying attributes of garlic, bolting habit has been the primary characteristic used to categorize garlic clones by horticulturists and botanists. Based on bolting habit, Helm (1956) (as cited by Hahn, 1996) classified garlic into three botanical varieties: nonbolting A. sativum var. sativum, bolting with twisted scape from central Asia A. sativum var. ophioscorodon; and bolting with nontwisted scape from south Asia A. sativum var. pekinense. Jones and Mann (1963) referred to the fact that some garlic clones flower and other clones never flower in their discussions about grouping clones, but they had reservations about classifying clones into distinct botanical varieties or horticultural groups because garlic clones in different groups share other characteristics. Beyond the taxonomic and horticultural classification, physiological studies have classified garlic into three types (Takagi, 1990): completebolting, incomplete-bolting, and nonbolting clones. Although complete-bolting and nonbolting clones represent uniform extremes of this characteristic, incomplete-bolting clones include plants with partially exserted and swollen inflorescences, 
bulbils within the pseudostem, or incompletely elongated scapes sometimes with nonbolting plants.

Nonbolting garlic clones are commonly grown around the world and they usually yield more than bolting clones (Engeland, 1991), which expend significant resources in stalk and bulbil formation (Etoh, 1985). Therefore, it has been hypothesized that nonbolting garlic clones were selected from bolting garlic clones by farmers over time (Etoh, 1985; Etoh and Simon, 2002), although a mechanism for this asexual selection remains unclear. Genetic diversity studies using isozymes, randomly amplified polymorphic DNA (RAPD), and amplified fragment length polymorphism (AFLP) markers were able to distinguish bolting, incomplete-bolting and nonbolting garlic clones from each other by clustering them into separate groups. These studies also demonstrated that there was significant genetic variation within and among groups of bolting garlic clones (Al-Zahim et al., 1997; Ipek et al., 2003; Maass and Klaas, 1995). These studies did not identify a particular molecular marker associated with bolting, but an easy-to-evaluate simple marker differentiating bolting garlic clones from nonbolting or incomplete-bolting ones could be useful to categorize clones in garlic germplasm collections, or to identify quickly garlic clones with a potential for flowering and seed production. Furthermore, such a marker could provide some insight into the molecular basis of this important trait.

Mutations detected in mitochondrial genomes including chimeric genes, rearrangements, deletions, and duplications of conserved mitochondrial genes have been associated with the cytoplasmic male sterility (CMS) in a range of plant species (Bach et al., 2002; Engelke and Tatlioglu, 2002; Gutierres et al., 1999; Schnable and Wise, 1998; Vedel et al., 1994). In this study we describe an unusual mitochondrial-plastid chimera detected in bolting garlic types and investigate the possible use of this chimera as a polymerase chain reaction (PCR)-based marker to discriminate bolting garlic clones from nonbolting or incomplete-bolting garlic clones.

\section{Materials and Methods}

Plant materials. Three hundred thirty-three garlic clones representing a wide range of phenotypic diversity obtained from North America, Europe, and Asia (Ipek et al., 2003) were planted at the West Madison Research Sta. field and in pots in the Walnut Street Greenhouse, both of which are located at the University of Wisconsin-Madison. This collection included 183 clones from the U.S. Department of Agriculture (USDA) Western Region Plant Introduction Sta., Pullman, WA, and 150 clones from various growers. Flowering data were collected from at least 10 plants/clone for at least 2 years in the field, except for 34 North American clones for which data were collected over 6 years (Table 1).

Sampling AND DNA Extraction. For each clone, leaves from at least two plants grown in the greenhouse and one plant grown in the field were lyophilized and independently analyzed. DNA was extracted from $\approx 200 \mu \mathrm{L}$ powdered leaf samples in microcentrifuge tubes using a modified cetyl trimethyl ammonium bromide (CTAB) method (Fütterer et al., 1995). DNA concentration of each sample was measured using a TKO 100 Mini-Fluorometer (Hoefer, San Francisco, $\mathrm{CA}$ ) adjusted to $30 \mathrm{ng} \cdot \mu \mathrm{L}^{-1}$ in tris-ethylenediamine tetraaceticacid (TE) buffer for PCR analysis.

Polymerase Chain Reaction Procedures. Oligonucleotide primers designed to amplify intergenic regions in the mitochondria of carrot (Daucus carota L.) (Bach, 2000) were used. Primers primarily targeted mitochondrial genes, but several chloroplast gene primers were included because they occur in the carrot mitochondrial genome (Bach, 2000; Bach et al., 2002). For initial screening, these oligonucleotide primers were pooled, and combinations of these primer pools were used to amplify intergenic regions of the garlic mitochondrion. When amplification of a DNA fragment was observed in primer-pool combinations, individual primer combinations were tested to identify the specific primer pair responsible for amplification of that DNA fragment. A total of 42 primer pairs were tested using the following PCR reaction conditions: each $25-\mu \mathrm{L}$ PCR reaction consisted of $0.75 \mathrm{U}$ DNA polymerase (PanVera, Madison, WI) with the reaction buffer supplied at $1 \times$ concentration, $0.8 \mu \mathrm{M}$ each primer, deoxyribonucleotide triphosphates (dNTPs) at $200 \mu \mathrm{m}$ each, and 90-ng template DNA. The reactions were heated to $94^{\circ} \mathrm{C}$ for 2 min followed by 40 cycles of $95^{\circ} \mathrm{C}$ for $20 \mathrm{~s}, 55^{\circ} \mathrm{C}$ for $1 \mathrm{~min}$, and $68^{\circ} \mathrm{C}$ for $4 \mathrm{~min}$. For these reactions, a Perkin Elmer model 9600 Thermal Cycler (Perkin Elmer, Wellesley, MA) was used. These reactions were size fractionated by electrophoresing through $1 \%(\mathrm{w} / \mathrm{v})$ agarose in $1 \times$ tris-acetate-ethylenediamine tetraacetic acid (TAE) buffer (40 mm Tris-acetate, with a $\mathrm{pH}$ of 8.0 , and $1 \mathrm{~mm}$ ethylenediamine tetraacetic acid) with a GeneRuler 1-kbp DNA ladder (Fermentas, Hanover, MD) as a DNA molecular weight marker. Gels were stained with ethidium bromide $\left(0.5 \mu \mathrm{g} \cdot \mathrm{mL}^{-1}\right.$; Sigma, St Louis) and photographed. Reaction conditions for the amplification of 1403-bp Bolt Marker (BltM) were the same as the procedure just described, except a 2-min extension time was used at $68^{\circ} \mathrm{C}$.

ISOLATION OF MITOCHONDRIAL DNA AND SPLINKERETTEPOLYMERASE CHAIN REACTION. Plants of selected bolting and nonbolting garlic clones were grown in the dark for 10 to $15 \mathrm{~d}$ to isolate mitochondrial DNA, which was extracted from $5 \mathrm{~g}$ of either etiolated young leaf or root tissue according to the method described by Triboush et al. (1998). To sequence

Table 1. Bolting phenotype of diverse garlic clones analyzed in this study and the amplification pattern of Bolt Marker (BltM).

\begin{tabular}{lcccccrrr}
\hline & \multicolumn{4}{c}{ Clones from each source (no.) } & & \multicolumn{2}{c}{ BltM amplification $^{z}$} \\
\cline { 2 - 5 } Flowering & Asia & Europe & North America & Unknown & Total (no.) & A (no.) & NA (no.) & A (\% of total) \\
\hline Bolting & 7 & 69 & 24 & 30 & 130 & 127 & 3 \\
Incomplete bolting & 4 & 43 & 0 & 25 & 72 & 3 & 69 \\
Nonbolting & 16 & 94 & 10 & 11 & 131 & 4.2 & 131 \\
Total & 27 & 206 & 34 & 66 & 333 & 130 & 203 \\
\hline
\end{tabular}

${ }^{\mathrm{z}} \mathrm{A}$, clones in which Bolt Marker (BltM) was amplified; NA, clones in which BltM was not amplified. 
characterize the flanking DNA, the splinkerette-PCR approach was carried out according to the protocol described by Devon et al. (1995), with minor modifications. Briefly, $60 \mathrm{ng}$ mitochondrial DNA was digested with either $B g l$ II, Xho I, or Hind III, according to protocols described by the supplier (Promega, Madison, WI). Restriction enzyme site-specific splinkerette adapters were ligated to digested DNA fragments according to the protocol described by the manufacturer of ligase (Promega). Each $50 \mu \mathrm{L}$ of primary splinkerette-PCR reaction mixture contained 1 U DNA polymerase (PanVera), with the reaction buffer supplied at $1 \times$ concentration, $320 \mathrm{nM}$ of each dNTPs, and $400 \mathrm{nM}$ primary splinkerette and specific primers, and $2 \mu \mathrm{L}$ ligated DNA solution. The reactions were heated to $94{ }^{\circ} \mathrm{C}$ for $2 \mathrm{~min}$, followed by 40 cycles of $95{ }^{\circ} \mathrm{C}$ for $20 \mathrm{~s}, 59^{\circ} \mathrm{C}$ for $1 \mathrm{~min}$, and $68^{\circ} \mathrm{C}$ for $7 \mathrm{~min}$. For these reactions, an Eppendorf Master Cycler (Eppendorf North America, Westbury, NY) was used. Secondary splinkerette-PCR was done using $2 \mu \mathrm{L} 100 \times$ diluted primary splinkerette product, secondary splinkerette primers, and the same reaction and thermal cycling conditions of primary splinkerette-PCR. Products of secondary splinkerette-PCR reactions were size fractionated as described earlier, but with $1.5 \%$ agarose.

Sequencing and Sequence analysis. Polymerase chain reaction-amplified DNA fragments were excised and purified from agarose gels using the QIAquick gel extraction kit (QIAGEN, Valencia, CA). They were cloned into the pGEM-T vector system (Promega) and transformed into JM109 competent cells (Promega) using the manufacturer's protocols. They were then sequenced using Taq DNA polymerase cycle-sequencing reactions, according to the conditions recommended by Applied Biosystems (Foster City, CA), with their BigDye reagents using fluorescent dye terminators. Sequencing was performed using a PE-Biosystem 377 XL automated DNA sequencing instrument (Applied Biosystems) at the Biotechnology Center in the University of Wisconsin-Madison. The nucleotide and putative amino acid sequences of PCR products were compared with the nucleotide or amino acid sequences in the GenBank databases using the BLASTN v.2.2.13 and BLASTX v.2.2.13 programs (National Center for Biotechnology Information, 2006).

\section{Results and Discussion}

I D E N T I F I C A T I O N A N D CHARACTERIZATION OF A CHIMERIC DNA fragment. Polymerase chain reaction analysis with primers $\mathrm{p} 1$ (5'-AAGGAGCATCACGTTGGCT TTG-3') and p3 (5'-GGGAA AGGGTAGAAGAATGGG-3' ) designed by Bach (2000) for carrot mitochondrial genome analysis amplified a 3763-bp DNA fragment (Fig. 1A) in bolting garlic clones in the diverse collection (Ipek et al., 2003) of University of WisconsinMadison, the genetic diversity of which had been analyzed. The $\mathrm{p} 1$ primer was developed from cox 3 consensus sequence for several species, whereas the $\mathrm{p} 3$ primer was developed from an rpl23 sequence that is usually associated with the chloroplast genome, but also occurs in the carrot mitochondrial genome (Bach et al., 2002) (GenBank accession no. AF301604). Amplification of this DNA fragment was not observed in either nonbolting or incomplete-bolting garlic clones in this collection (Fig. 1A). The garlic clones in which the 3763-bp DNA fragment amplified bolted uniformly produced fully elongated scapes and well-developed, numerous flowers on all plants every year in Wisconsin.

A BLAST search for homologous sequences in the GenBank databases indicated that this 3763-bp DNA fragment contained the $3^{\prime}$ end of the mitochondrial cox3 gene and the chloroplast genes $p s b A$, rps 19, trnH, rpl2, and rpl23 (Fig. 2). Analysis of DNA sequences flanking this chimeric DNA fragment obtained using splinkerette-PCR in garlic clone, U094, indicated that $\approx 4.8$-kbp chloroplast DNA was present in the garlic mitochondrial genome downstream from cox3. A BLASTN search showed that the 4.8-kbp chloroplast DNA contained the $p s b A$, rps 19, trnH, rpl2, rpl23, trnI, ycf2, and orf2280 genes (Fig. 2). Sequences of chloroplast genes in this chimeric fragment were highly diverged from that of other plant species, including arabidopsis [Arabidopsis thaliana (L.) Heynh.], wheat (Triticum aestivum L.), and rice (Oryza sativa L.), and included numerous deletions and insertions that resulted in incomplete open reading frames or frame shift mutations (data not presented), suggesting that the chloroplast genes in this chimeric region are not functional copies. This observation led us to believe that there should be functional copies of these diverged chloroplast genes. Indeed, the 5' end of another copy of $p s b A$ including the start codon was partially cloned in both bolting and nonbolting garlic clones using primers based on the conserved sequences of $p s b A$ genes in GenBank. No polymorphism was observed between the amino acid sequences of
$\mathbf{A}$ A B

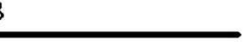
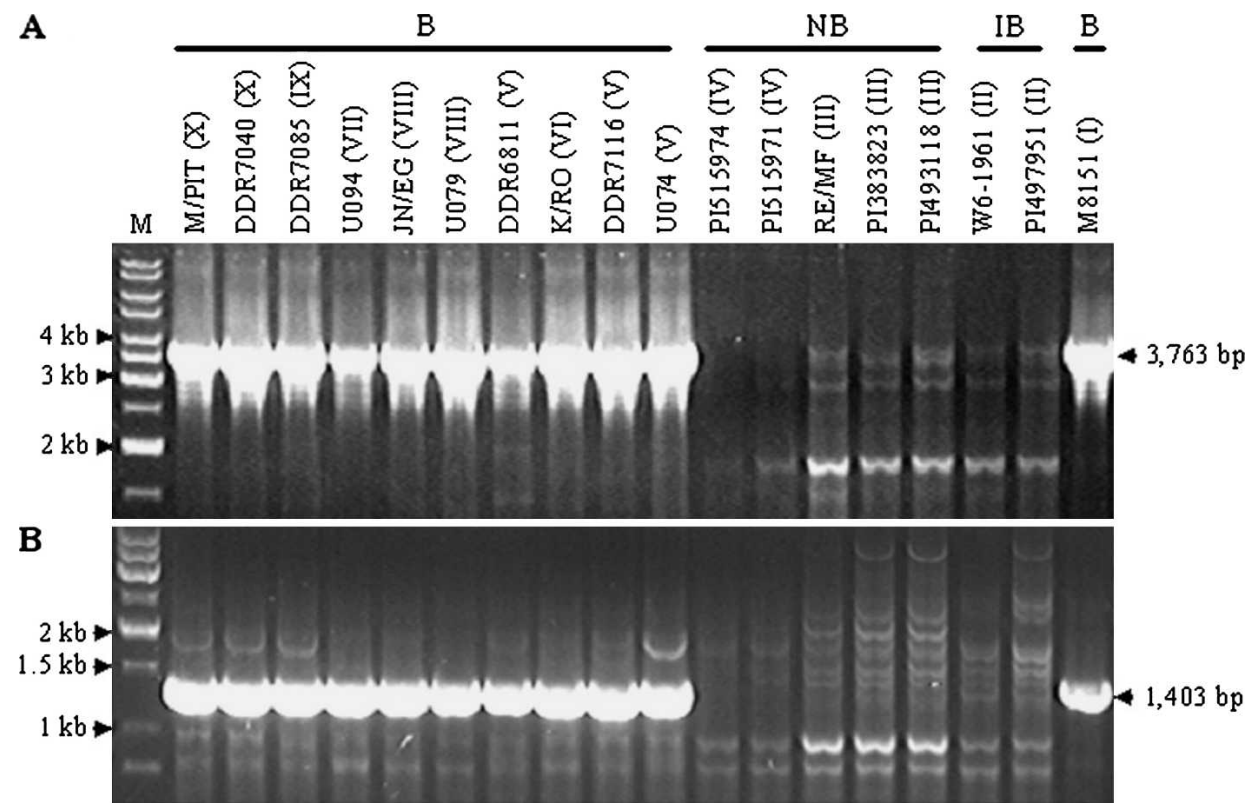

Fig. 1. Polymerase chain reaction amplification of the 3763-bp DNA fragment with the primer combination p1 plus $\mathrm{p} 3$ (A) and the 1403-bp DNA fragment [Bolt Marker (BltM)] with the primer combinationp1 plus p2 (B) in a subsample of diverse garlic clones. B, NB, and IB indicate bolting, nonbolting, and incomplete bolting garlic clones respectively. Roman numerals within parentheses are the amplified fragment length polymorphism groupings of garlic clones assigned by Ipek et al. (2003). M indicates DNA molecular weight markers. 


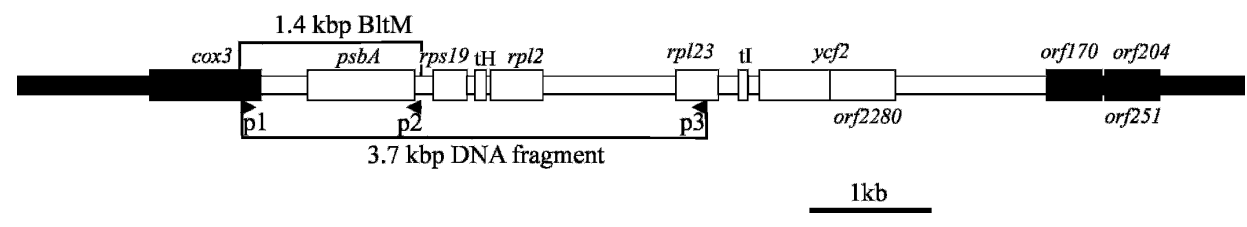

Fig. 2. Diagrammatic representation of the chimeric mitochondria-chloroplast DNA fragment in the garlic mitochondria based on the comparison of its nucleotide sequences with the GenBank databases. Black and white boxes indicate mitochondrial and chloroplast DNAs respectively. $\mathrm{tH}=\operatorname{trnH}, \mathrm{tI}=\operatorname{trnI}$.

this copy of $p s b A$ and the amino acid sequences of $p s b A$ genes in rice and wheat, suggesting that this is likely the functional copy of the $p s b A$ gene in the garlic chloroplast genome (data not presented). On the other hand, the mitochondrial $\operatorname{cox} 3$ gene in this chimeric DNA fragment had a complete open reading frame with few changes in amino acid sequence compared with cox3 of other plant species (data not presented), suggesting it could also be functional. Furthermore, BLASTX showed that putative amino acid sequences of DNA immediately flanking the $3^{\prime}$ end of chloroplast orf 2280 in the chimeric region significantly matched with those of mitochondrial orf 251 and orf 204 in arabidopsis, and mitochondrial orf170 in sugar beet (Beta vulgaris L.), thus indicating that both the $5^{\prime}$ and $3^{\prime}$ ends of the plastid DNA fragment in this chimeric region are flanked by mitochondrial DNA (Fig. 2).

Collectively, our results suggest that the chimeric DNA resulted from the insertion of about $4.8 \mathrm{kbp}$ of chloroplast DNA into the mitochondrial genome of garlic. In fact, it has been demonstrated that incorporation of plastid DNA into the mitochondrial genome occurred in other plant species. Notsu et al. (2002) found that chloroplast DNA accounts for $6.3 \%$ of the 490.5-kbp rice mitochondrial genome. Similarly, Kubo et al. (2000) demonstrated that $2.1 \%$ of the $368.8-\mathrm{kbp}$ sugar beet mitochondrial genome is composed of chloroplast DNA. In the rice mitochondrion, 17 chloroplastlike DNA insertions were detected, and the sizes of these insertions ranged from 32 to $6653 \mathrm{bp}$ (Notsu et al., 2002). Taken together, these findings demonstrate that a significant amount of chloroplast DNA may be present in the mitochondrial genome. On the other hand, insertion of foreign DNA into the chloroplast genome is rare, and in fact, no insertion of mitochondrial genes was found in the complete chloroplast genome of either arabidopsis or maize (Zea mays L.) (Maier et al., 1995; Sato et al., 1999).

The gene order of plastid genes found in the chimeric region of garlic is the same as that in the chloroplast genomes of maize (NC_001666), rice (NC_001320), wheat (NC_002762), and arabidopsis (NC_000932). Maier et al. (1995) indicated that rps 19, trnH, rpl2, rpl23, and trnI were located on both inverted repeats $\mathrm{A}$ and $\mathrm{B}$ in the chloroplast genome of maize, in the same order. However, these genes are flanked by $p s b A$ only in the inverted repeat $\mathrm{A}$ of maize, rice, wheat, and arabidopsis, and the orientation of these genes was conserved in rice, arabidopsis, and wheat. Conservation of gene order and position of genes on the chloroplast genome indicate that this $4.8-\mathrm{kbp}$ chloroplast DNA fragment in the mitochondrial genome of garlic likely originated from the inverted repeat $\mathrm{A}$ and $p s b \mathrm{~A}$ gene region of the garlic chloroplast.

ASSOCIATION OF THE CHIMERIC MITOCHONDRIA-CHLOROPLAST REGION WITH THE BOLTING PHENOTYPE OF GARLIC. We evaluated 333 garlic clones from Asia, Europe, North America, or unknown geographic origins. Of these, no plants bolted in
131 clones and all plants bolted in 130 clones, so these clones were categorized as nonbolting and bolting respectively (Table 1$)$. Flowering incidence observed in this study was the same as, or greater than, that reported from the USDA collection. Based upon the observations of Kamenetsky et al. (2004), this is not unexpected because the colder Wisconsin winter climate of our study induces a higher incidence of flowering than the warmer winter California climate, where the USDA collection has been evaluated. Most plants in bolting clones formed prominent flower stalks that grew vigorously and robust inflorescences with flowers and bulbils. A few bolting plants formed weak flower stalks and inflorescences, but this was usually restricted to one or two plants that also had chlorotic or striped leaves. For a few bolting clones, leaves were healthy, but although all plants bolted, flower stalks were weak and inflorescences failed to develop fully. In the remaining 72 clones, less than $100 \%$ of the plants bolted, and those that did bolt had weak stalks and inflorescences, and they included plants with partially exserted and swollen inflorescences, bulbils within the pseudostem, or incompletely elongated scapes. These were categorized as incomplete bolting as previously suggested by Takagi (1990).

The usefulness of this chimeric DNA fragment for differentiating bolting garlic clones from incomplete or nonbolting ones was evaluated in 333 garlic clones. For this purpose, primers p1 plus p2 (5'-CAG CAG CCA GGT GCG AAG C-3') producing a 1403-bp DNA fragment in bolting clones but not in nonbolting/incomplete-bolting clones (Fig. 1B) were used for screening. The amplification pattern of this 1403-bp fragment coincided with that of the 3763-bp DNA fragment in 18 diverse clones evaluated for both PCR products. We therefore chose this smaller DNA fragment for further screening for reasons of convenience. This 1403-bp DNA fragment amplified with the p1 and p2 primers was referred to as BltM (M. Ipek, A. Ipek, and P.W. Simon, unpublished). Bolt Marker was observed in 130 of 333 garlic clones (39\%) analyzed, of which 127 were bolting and three were incomplete bolting (Table 1). Bolt Marker was not amplified in any of the remaining 203 garlic clones representing $61 \%$ of the collection. Of these 203 clones, three were bolting clones, 69 were incomplete-bolting clones, and 131 clones were nonbolting.

In the germplasm evaluated, 72 clones $(21.6 \%)$ were incomplete bolting and produced flower stalks at an incidence that ranged from $7 \%$ to $88 \%$ (data not presented). Nearly all of these stalks were smaller than in bolting clones, and floral development rarely resulted in fully formed fertile flowers. Bolt Marker was not amplified in $69(95.8 \%)$ of these 72 clones (Table 1). However, this marker was amplified in three clones with incomplete-bolting phenotypes, and the incidence of production of visible flower stalk for these three clones was $13 \%, 50 \%$, and $75 \%$. Although all plants in the three clones without BltM produced visible flower stalks, their flower stalks were weak and senesced early, like those in incomplete-bolting clones, and unlike the other 127 bolting clones with flower stalks that grew vigorously. We speculate that these clones belong to the incomplete-bolting group, in terms of floral development, even though $100 \%$ of the plants bolted. Overall, BltM successfully differentiated bolting garlic clones from nonbolting and 
incomplete-bolting garlic clones in 327 (98\%) of 333 garlic clones, indicating that this association is not random.

Relatively large collections of garlic germplasm are being assembled worldwide, and plant exploration is likely to expand these collections (Al-Zahim et al., 1997; Etoh and Simon, 2002; Ipek et al., 2003; Maass and Klaas, 1995; Simon and Jenderek, 2003). Given the importance of flowering to garlic growers and researchers, as well as the variation in flowering that comes with varying environments (Kamenetsky et al., 2004), a systematic evaluation of flowering incidence over several seasons and growing locations will be of great interest. As that field information is assembled, a comparison with flowering incidence predicted from BltM will be valuable in determining the usefulness of this marker over diverse locations.

Mitochondrial markers have also been associated with another reproductive trait in species of the genus Allium L. - namely, CMS. Use of mitochondrial variation in onion (A. cepa L.) (Engelke et al., 2004a; Sato, 1998) and chives (A. schoenoprasum L.) (Engelke and Tatlioglu, 2002) to distinguish male-sterile cytoplasm from male-fertile cytoplasm has been suggested, although interestingly it is differences in the plastid genome, which co-occur with different mitochondrial genomes, that are usually used to evaluate onion cytoplasm (Havey, 1995). Mitochondrial variation in leek (A. ampeloprasum L.) has also been associated with male sterility (Engelke et al., 2004b). Although cytoplasmic male sterility has consistently been associated with the mitochondrial genome in many plant species, flowering is controlled by nuclear genes. This is the first report associating the initiation of flowering with cytoplasmic factors. Perhaps, the association of variation in the garlic mitochondrial genome with the capacity for flowering in this study reflects coevolution of its mitochondrial genome and gene(s) controlling flower stalk production in the garlic nuclear genome. Because both the plastid and mitochondrial genomes are maternally inherited, we conjecture that there could be numerous other mitochondrial and perhaps even plastidic indels and single nucleotide polymorphisms (SNPs) that are inherited coincidentally with the BltM. For that matter, several garlic diversity studies have clustered bolting and nonbolting clones separately (Al-Zahim et al., 1997; Ipek et al., 2003; Maass and Klaas, 1995). We might presume that both the nuclear and cytoplasmic genomes contributed to the RAPD and AFLP variations that accounted for that clustering. Consequently, it may in fact be variation in the nuclear genome that contributes to the presence or absence of flowering. Studies to evaluate gene expression in flowering and nonflowering garlic clones may further elucidate the molecular basis of this trait.

The mitochondrial genome of plants generally is more tolerant of insertions and deletions than the plastid genome. Although it does not seem likely that this insertion should be the basal cause of garlic flowering, those plastid genes in this chimeric region appear to be mutated and, consequently, likely became dysfunctional. Numerous insertions, deletions (indels), and SNPs in chloroplast DNA in this chimeric region suggest that this insertion is an ancient event in the evolution of garlic. A more complete analysis of the mitochondrial genomes of complete-bolting, incomplete-bolting, and nonbolting clones, including assessment of indel and SNP sequence variation of the chimeric region, should provide more clues about the origin of this long-cultivated horticultural crop.

Extensive evaluation of hybrid progeny in garlic has not been reported, although seed production and genetic mapping in garlic has been successful, (Etoh and Simon 2002; Ipek et al., 2005; Simon and Jenderek, 2003; Zewdie et al., 2005). Genetic diversity studies demonstrated that bolting garlic clones are distinct from nonbolting and incomplete ones, and there are also differences among each of these three types of garlic, especially among the bolting clones. However, the chimeric marker we described in this study revealed that $97.7 \%$ of the bolting clones share this region. With increasing importance of garlic seed production for breeding purposes and elimination of viruses and nematodes, BltM will be interesting to follow in sexual progeny and it could be very useful for identifying garlic clones with a bolting phenotype. This marker can also be a useful tool for screening germplasm accessions quickly to identify bolting garlic clones that have potential for breeding.

\section{Literature Cited}

Al-Zahim, M., H.J. Newbury, and B.V. Ford-Lloyd. 1997. Classification of genetic variation in garlic (Allium sativum L.) revealed by RAPD. HortScience 32:1102-1104.

Bach, I.C. 2000. Molecular breeding of carrot (Daucus carota L.). Royal Veterinary and Agricultural University, Frederiksberg, Denmark, PhD Diss.

Bach, I.C., A. Olesen, and P.W. Simon. 2002. PCR-based markers to differentiate the mitochondrial genomes of petaloid and male fertile carrot (Daucus carota L.). Euphytica 127:353-365.

Devon, R.S., D.J. Porteous, and A.J. Brookes. 1995. Splinkerettesimproved vectorettes for greater efficiency in PCR walking. Nucl. Acids Res. 23:1644-1645.

Engeland, R.L. 1991. Growing great garlic: The definitive guide for organic gardeners and small farmers. Filaree Productions, Okanogan, WA.

Engelke, T., E. Agbicodo, and T. Tatlioglu. 2004b. Mitochondrial genome variation in Allium ampeloprasum and its wild relatives. Euphytica 137:181-191.

Engelke, T. and T. Tatlioglu. 2002. A PCR-marker for the $\mathrm{CMS}_{1}$ inducing cytoplasm in chives derived from recombination events affecting the mitochondrial gene atp9. Theor. Appl. Genet. 104: 698-702.

Engelke, T., T. Terefe, and T. Tatlioglu. 2004a. A PCR-based markersystem monitoring CMS-(S), CMS-(T), and (N)-cytoplasm in the onion (Allium cepa L.). Theor. Appl. Genet. 107:162-167.

Etoh, T. 1985. Studies on the sterility in garlic, Allium sativum L. Memoirs of the Faculty Agr. (Kagoshima Univ.) 21:77-132.

Etoh, T. and P.W. Simon. 2002. Diversity, fertility and seed production of garlic, p. 101-117. In: H.D. Rabinowitch and L. Currah (eds.). Allium crop science: Recent advances. CAB International, New York. Fütterer, J., A. Gisel, V. Iglesias, A. Kloti, B. Kost, O. MittelstenScheid, G. Neuhaus, G. Neuhaus-Url, M. Schrott, R. Shillito, G. Spangenberg, and Z.Y. Wang. 1995. Standard molecular techniques for the analysis of transgenic plants, p. 215-218. In: I. Potrykus and G. Spangenberg (eds.). Gene transfer to plants. Springer-Verlag, New York.

Gutierres, S., B. Combettes, R. De Paepe, M. Mirande, C. Lelandais, F. Vedel, and P. Chetrit. 1999. In the Nicotiana sylvestris CMSII mutant, a recombination-mediated change $5^{\prime}$ to the first exon of the mitochondrial nadl gene is associated with lack of the NADH: Ubiquinone oxidoreductase (complex I) NAD1 subunit. Eur. J. Biochem. 261:361-370.

Hahn, G. 1996. History, folk medicine and legendary uses of garlic, p. 1-34. In: H.P. Koch and L.D. Lawson (eds.). Garlic, the science and therapeutic application of Allium sativum L. and related species. 2nd ed. Williams and Wilkins, Baltimore, MD.

Havey, M.J. 1995. Cytoplasmic determinations using the polymerase chain reaction to aid in the extraction of maintainer lines from openpollinated populations of onion. Theor. Appl. Genet. 90:263-268. 
Helm, J. 1956. Die zu wurz- und speisezwecken kultivierten arten der gattung Allium L. Kulturpflanze 4:130-180.

Ipek, M., A. Ipek, S.G. Almquist, and P.W. Simon. 2005. Demonstration of linkage and development of the first low-density genetic map of garlic based on AFLP markers. Theor. Appl. Genet. 110: 228-236.

Ipek, M., A. Ipek, and P.W. Simon. 2003. Comparison of AFLPs, RAPD markers, and isozymes for diversity assessment of garlic and detection of putative duplicates in germplasm collections. J. Amer. Soc. Hort. Sci. 128:246-252.

Jones, H.A. and L.K. Mann. 1963. Onions and their allies. Leonard Hill Books, London.

Kamenetsky, R., I.L. Shafir, H. Zemah, A. Barzilay, and H.D. Rabinowitch. 2004. Environmental control of garlic growth and florogenesis. J. Amer. Soc. Hort. Sci. 129:144-151.

Koul, A.K., R.N. Gohil, and A. Langer. 1979. Prospects of breeding improved garlic in the light of its genetic and breeding systems. Euphytica 28:457-464.

Kubo, T., S. Nishizawa, A. Sugawara, N. Itchoda, A. Estiati, and T. Mikami. 2000. The complete nucleotide sequence of the mitochondrial genome of sugar beet (Beta vulgaris L.) reveals a novel gene for tRNA(Cys)(GCA). Nucl. Acids Res. 28:2571-2576.

Maass, H.I. and M. Klaas. 1995. Infraspecific differentiation of garlic (Allium sativum L.) by isozyme and RAPD markers. Theor. Appl. Genet. 91:89-97.

Maier, R.M., K. Neckermann, G.L. Igloi, and H. Kossel. 1995. Complete sequence of the maize chloroplast genome: Gene content, hotspots of divergence and fine tuning of genetic information by transcript editing. J. Mol. Biol. 251:614-628.

National Center for Biotechnology Information. 2006. Basic Local Alignment Search Tool (BLAST) 23 Mar. 2006. <http://www. ncbi.nlm.nih.gov/BLAST/>.
Notsu, Y., S. Masood, T. Nishikawa, N. Kubo, G. Akiduki, M. Nakazono, A. Hirai, and K. Kadowaki. 2002. The complete sequence of the rice (Oryza sativa L.) mitochondrial genome: Frequent DNA sequence acquisition and loss during the evolution of flowering plants. Mol. Genet. Genomics 268:434-445.

Pooler, M.R. and P.W. Simon. 1993. Characterization and classification of isozyme and morphological variation in a diverse collection of garlic clones. Euphytica 68:121-130.

Sato, Y. 1998. PCR amplification of CMS-specific mitochondrial nucleotide sequences to identify cytoplasmic genotypes of onion (Allium cepa L.). Theor. Appl. Genet. 96:367-370.

Sato, S., Y. Nakamura, T. Kaneko, E. Asamizu, and S. Tabata. 1999. Complete structure of the chloroplast genome of Arabidopsis thaliana. DNA Res. 6:283-290.

Schnable, P.S. and R.P. Wise. 1998. The molecular basis of cytoplasmic male sterility and fertility restoration. Trend Plant Sci. 3:175180.

Simon, P.W. and M.M. Jenderek. 2003. Flowering, seed production and the genesis of garlic breeding. Plant Breed. Rev. 23:211-244.

Takagi, H. 1990. Garlic (Allium sativum L.), p. 109-146. In: J.L. Brewster and H.D. Rabinowitch (eds.). Onions and allied crops: Biochemistry, food science, and minor crops. Vol. 3. CRC Press, Boca Raton, FL.

Triboush, S.O., N.G. Danilenko, and O.G. Davydenko. 1998. A method for isolation of chloroplast DNA and mitochondrial DNA from sunflower. Plant Mol. Biol. Rptr. 16:183-189.

Vedel, F., M. Pla, V. Vitart, S. Gutierres, P. Chetrit, and R. De Paepe. 1994. Molecular basis of nuclear and cytoplasmic male sterility in higher plants. Plant Physiol. Biochem. 32:601-618.

Zewdie, Y., M.J. Havey, J.P. Prince, and M.M. Jenderek. 2005. The first genetic linkages among expressed regions of the garlic genome. J. Amer. Soc. Hort. Sci. 130:569-574. 